\title{
A retrospective study on health-related quality of life in congenital clubfoot (with patient-reported outcomes)
}

\author{
Aliz Bohner-Beke1, Szilvia Jámbori², Lívia Vass³ ${ }^{3}$ János Kránicz4, \\ Veronika Végh', Henriette Pusztafalvi ${ }^{5}$
}

When treating clubfoot, doctors prefer objective measurements, while knowing the subjective quality of life of a patient is secondary rather than observing the two in parallel. The aim was to highlight the significance of patient reporting in the quality of life questionnaires. This retrospective study included 75 patients with clubfoot (44 boys and 28 girls, mean age 12.45 (range 2-30 years; 3 missing). The treatment was typical in 55 patients (posteromedial release), while Ponseti method was used in 20 patients. The following questionnaires were used: EQ-5D-3L and Clubfoot Disease Specific Instrument for Health Science, Rosenberg Scale for Psychological Sapiens, and our own sociological questionnaire. The mean EQ-5D index was 0.86 and mean EQ-VAS was 79.92, scoring lower than the Hungarian population data. According to the results of the special quality of life questionnaire, foot pain and finding shoes that fit caused the biggest problems for the study patients. The quality of life questionnaire results showed that finding shoes that fit without exacerbating pain was the biggest problem for study participants. The mean Rosenberg scale score was 22.2 (maximum 30) points. There were no significant findings in individual cases, however, correlations were found when examining low-self-evaluation participants in the group. Internal consistency of the instruments employed was appropriate (Cronbach alpha: 0.831-0.939), and combined questionnaires used to identify each aspect as indicated by the medium and high Spearman correlation values (rs=0.539-0.916).

Key words: CLUBFOOT; QUALITY OF LIFE; PATIENT REPORTED OUTCOME MEASURES

\section{INTRODUCTION}

In order to verify the effective treatment of clubfoot, doctors prefer objective measurements and mostly examine motion range of the leg joints, the heel and/or foot position, muscle functions, and the heel load during walking. Meanwhile, due to short time of visits, the patient's issues concerning shoes and their narrowed social relationships may not be discussed. These factors would contribute to better understanding patient difficulties in everyday life.

Typical clinical evaluation methods (movement range, $x$-ray, gait analysis) do not reflect accurately how patients with clubfoot use their feet at home or school/workplace and what problems they cause for the child/parent. Patient selfevaluation coupled with the physician's evaluation can help create a better picture of the patient somatic, psychological and social aspects.
From the health point of view, self-evaluation based reports are widely used by professionals. Roye et al. used the FSIIrPediatric Functional Status in 46 patients having undergone a surgical procedure and established a patient-based scale called Clubfoot Disease Specific Instrument (DSI) (1). Vitale

\footnotetext{
1 University of Pécs, Faculty of Health Sciences, Health Sciences PhD School, Pécs, Hungary

2 University of Szeged, Institute of Psychology, Szeged, Hungary ${ }^{3}$ University of Pécs, Faculty of Sciences, Institute of Sports Sciences and Physical Education, Pécs, Hungary

${ }^{4}$ University of Pécs, Faculty of Health Sciences, Institute of Phisyotherapy and Sports Science, Pécs, Hungary

${ }^{5}$ University of Pécs, Faculty of Health Sciences, Institute of Health Insurance, Pécs, Hungary
}

\section{Correspondence to:}

Aliz Bohner-Beke, MSc, PhD, University of Pécs, Faculty of Health Sciences, Health Sciences PhD School, Szivárvány u. 28/D, 6500 Baja, Hungary, e-mail: bohner.beke@gmail.com

Primljeno/Received: 12. 10. 2018., Prihvaćeno/Accepted: 06. 02. 2019. 
et al. in their 16-year follow-up study used DSI and the Child Health Questionnaire (CHQ). The authors found that the quality of life of young people was relatively high after surgery when compared to the quality of life of young athletes of the same age (2). Bor et al. carried out a follow-up study on the effectiveness of the Ponseti treatment in 74 newborns; they also investigated the Pirani point system, the number of plasters, the necessity of Achilles tenotomy, application of bracing, movement of the ankle, as well as the parents'judgement with DSI (3). Morris et al. performed psychometric testing by the Oxford Ankle Foot Questionnaire for Children (OXAFQ-C) cluster questionnaire with the use of Kidscreen (4). Dietz et al. used DSI and PedsQL 4.0 child health questionnaire in their research. Their results showed DSI to be sensitive to different treatment techniques and disease severity (5). Engell et al. employed the SF-12 (SF-12 PCS, SF-12 MCS) questionnaires and concluded that HRQOL was only significant at the physical level, while there were no differences in the mental scale between the two groups (6). Wallander et al. used the SF-36 (Short Form (36) Health Survey), EQ-5D (EuroQol) and American Association of Orthopedic Surgeons (AAOS) Foot and Ankle Outcomes Questionnaire instruments (7). Graf et al. assessed walking, muscle strength and leg movements using the following questionnaires: SF-36, Ankle/Hindfoot and Midfoot scales (AOFAS), Foot Function Index (FFI) and DSI. The questionnaire survey showed that patients were active during their daily activities but reported pain when walking, standing, stepping, and jumping. The mental and social health scales showed no difference between the two groups (8). Church et al. compared the results of surgical and Ponseti treatment with multiple measurement methods and questionnaires including the Pediatric Outcomes Data Collection Instrument (PODCI), Activities Scale for Kids (ASK), DSI and Dimeglio Scale (9). Duffy et al. asked both parents and children to complete the OxAFQ questionnaire along with physical examinations (10). Chu et al. investigated post-calcaneocuboid arthrodesis in regressive cases, supplemented by the Hospital for Joint Disease Functional Rating System (DSL), AAOS Foot and Ankle Outcomes Questionnaire, and the functional scoring system of Laaveg and Ponseti for patients with clubfoot (11). Sæetersdal et al. used the following questionnaires: Functional Rating System for clubfoot and DSI in their comparative study (surgical versus Ponseti). They determined the range of motion of the leg, discrepancies of the leg circle, and leg and shin length (12). Lin et al. summarized seven approaches to the methodological considerations that emerged in relation to $\mathrm{HRQOL}$ measurement (13). Based on this study, our choice to measure the overall quality of life was the EQ-5D-3L (Hungarian version) questionnaire because it is quick and easy to fill out, it is free after registration, and there are Hungarian data for comparability with other diseases. Based on the literature review, the selected quality of life questionnaire was the DSI (validated Hungarian version). No knowledge exists about the psychological and social factors affecting the quality of life of people living with clubfoot. In order to get to know the psychological aspect, we examined the self-evaluation and classic self-assessment questionnaire plus Rosenberg scale (14-17). In order to determine sociological factors, we compiled our own questionnaire with a sociologist's guidance.

The aim of the authors was to investigate the subjective factors influencing individual subjective self-assessment and quality of life of patients with congenital structural clubfoot. Responses can be highlighted from several aspects related to different disciplines, and our aim was to emphasize the multidisciplinary nature of the subject, which we tried to separate from each viewpoint and to synthesize the results and search for correlations.

\section{PATIENTS AND METHODS}

Study participants were patients from the Department of Orthopaedics, Clinical Centre, University of Pécs. A total of 189 envelopes were sent to respondents. The final group of respondents consisted of 75 participants with structural clubfoot, including 44 (61.1\%) male and 28 (38.9\%) female, (3 missing), aged 2-44 (mean \pm standard deviation (SD) $12.45 \pm$ 9.9) years. The three age groups were defined as follows:

- group 1 (age 2-11.99) included 38 (50.7\%) children. Data on their quality of life could only be obtained indirectly, through their proxy-reported DSI (valid Hungarian version);

- group 2 (age 12-17.99) included 20 (26.27\%) children who could independently comment on their own status. In this group, the child filled out the clubfoot DSI (selfreported) and one of the parents filled out the parent version of the questionnaire (DSI proxy-reported) in addition to the EQ-5D-3L questionnaire, Rosenberg scale and sociological questionnaire; and

- group 3 included 17 (22.7\%) subjects, all adults living with clubfoot and their quality of life was expressed through the DSI and EQ-5D-3L questionnaire, Rosenberg scale and sociological questionnaire.

The DSI questionnaires sent to the patients showed minimal difference among the three groups. Among the 75 respondents, 55 (73.3\%) patients received traditional treatment and 20 (26.7\%) were treated using the Ponseti technique.

Statistical analyses were performed using the SPSS Statistics 22. Looking at the results of our calculations, differences between the means and medians indicated a non-normal 
sample distribution, so the Mann-Whitney test was used to analyse significant differences between the two variables.

Since we used questionnaires and surveys with different research backgrounds, we needed to evaluate it in percentages and transform it into a 0-100 system that provided the accuracy required for statistical processing. Differences between the DSI items and certain dimensions of the EQ-5D were calculated using the Spearman rank correlation. The correlation coefficient was considered weak if $r s<0.3$, medium if $r s=0.3-0.6$, and strong if $r s>0.6$. For the internal consistency of the questionnaires, Cronbach's alpha values above 0.7 were considered acceptable (18).

\section{RESULTS}

\section{Results of the health perspective study}

Impacting overall quality of life is most noticeable within the 'pain/malaise' dimension, followed by 'normal activity', while the five dimensions of self-reliance are least affected. In the experimental group, the mean EQ-5D index was 0.89 $(n=37, \min 0.27$, $\max 1.00$, standard deviation $=0.17)$ and mean EQ-VAS 79.92. No significant correlation was found between EQ-5D index values and age, non-involvement or involvement. Based on the mean score and median values of the specific quality of life questionnaire (DSI), decline most pronounced in the quality of life and least pronounced in conductive and moderate exercise in the area of 'foot pain' and 'appropriate shoe acquisition'. In case of the selfreported DSI, there was a significant difference in the $6^{\text {th }}$ 'foot pain' ( $U=117.00 ; Z=-2.173 ; p=0.030)$, according to which those aged $>18$ years reported less pain. In case of the proxy-reported DSI, we found significant difference in 6 of 10 items, as well as in total DSI ( $U=173.00$; $Z=-3.189$; $\mathrm{p}=0.001$ ). The parents of children aged 2-11 years reported a higher quality of life than those aged 12-17. The proxy-reported DSI satisfaction subscale $(U=169.00 ; Z=-3.264$; $p=0.001)$ and function subscale $(U=187.50 ; Z=-2.964$; $p=0.003$ ) also showed significant age differences. Parents of older children were more dissatisfied and felt the child's leg function was worse. For the proxy-reported DSI, the 'satisfaction with the leg status' $(U=234.50 ; Z=-1.951 ; p=0.05)$ and the third 'slash' items $(U=250.50 ; Z=2.047 ; p=0.04)$ showed significant gender differences. Parents of girls were more satisfied with the status of their child's legs. In the proxy-reported total DSI questionnaire $(U=213.50, Z=-2.622$, $p=0.009$ ) and two subscales (satisfaction subscale: $U=236.00$, $Z=-2.250, \quad p=0.024$ and function subscale: $U=202.00$, $Z=-2.835, p=0.005)$, there was a significant difference between the questionnaire $5^{\text {th }}$ item and the methods of treatment, revealing that parents of children receiving Ponseti treatment felt better about their child's clubfoot.

\section{Results of psychological examination}

The Rosenberg scale mean score was 22.27 (median 24.00; standard deviation (SD) 6.91; interval 6.00-30.00). Out of the 37 study subjects, low self-evaluation was reported (below 15) by 5 individuals. Observing the Rosenberg scale and its total score, we did not find significant differences according to age, gender, or involvement. Significant differences were recorded between the low self-evaluated group and the 'normal' self-evaluated group in the sociological questionnaire $(U=8.00, Z=-3.153, p=0.002), E Q-5 D$ questionnaire $(U=10.50, Z=-3,189 ; p=0,001)$ and transformed (0-100) scores of the (self-reported) DSI questionnaire $(U=11.00$, $Z=-2.996, p=0.003)$. The low self-evaluated group was characterized by lower sociological satisfaction (mean 28.14, median 16.67, SD 27.27) compared to normal self-evaluated (mean 82.22, median 91.11; SD 19.90). Similarly, this was true for analyzing the EQ-5D questionnaire, meaning that the low self-evaluated group had worse subjective assessment of their overall health state (mean 52.00, median 50.00, SD 22.80) than the normal self-evaluated group (mean 87.93, median 100.00, SD 15.89). The difference could also be justified by the (self-reported) DSI. The low self-evaluated group was worse in judging the specific quality of life (mean 26.66, median 26.66, SD 18.86) than the normal self-evaluated group (mean 56.08, median 60.00, SD 19.79). Statistically measurable relationships were found between the two groups and measuring instruments of sociological questionnaire ( $r s=-0.549 ; \quad p=0.001), E Q-5 D$ index ( $r s=-0.55$; $p=0.001)$ and (self-reported) DSI.

\section{Results of the sociological questionnaire}

Based on the mean and median values of the 0-100 transformation, those with clubfoot felt most disadvantaged when planning activities involving walking (mean 64.86; median 70.00), followed by a trip (mean 69.72, median 80.00), and after two functional limitations, the third lowest mean was recorded on reaching life goals (mean 70.54, median 90.00), i.e. the involvement affected the future. Considering difference between the two age groups, we found a significant difference in the performance of school/workplace assignments $(U=111.500 ; Z=-1.977 ; p=0.048)$, according to which the condition of clubfoot did not hinder the individuals aged >18 (mean 91.76, median 100.00; scattering 24.04) versus those aged 12-17.99 years (mean 79.00; median 85.00; SD 26.73). Gender difference was also significant $(U=75.000, Z=-2.987, p=0.003)$ in case of school- and work-related tasks. Clubfoot was less likely to hinder work/ school-related tasks in girls (mean 98.57, median 100.00, scattering 3.631) compared to boys (mean 76.52, median 90.00, SD 30.09). 
Observing the involvement, there was a significant difference in the excursion related questions $(U=107.500$; $Z=-1.958 ; \quad p=0.05)$ and social relationships $(U=127.00$; $Z=-1.919 ; p=0.05)$. The condition of one-sided clubfoot (mean 83.53; median 100.00; SD 19.981) had less influence during excursion on the individual than double-sided clubfoot (mean 58.00; median 75.00;). The formation of social relationships was less inhibited in those with one-sided clubfoot (mean 98.00, median 100.00, scattering 8.24) versus bilateral involvement (mean 78.25, median 100.00, SD 37.53). A significant difference was found in 5 questions of the sociological questionnaire and total score $(U=107.5$; $Z=-1.945, p=0.05$ ) according to the place of residence (rural: mean 66.67; median 78.70; SD 31.99; and urban: mean:

TABLE 1. Mean values of the measuring instruments used in the $0-100$ system

\begin{tabular}{ll}
\hline Scale & Mean \\
Clubfoot Disease Specific Instrument: DSI (proxy-reported) & 67.25 \\
Clubfoot Disease Specific Instrument: DSI (self-reported) & 56.22 \\
EQ-5D-3L & 83.78 \\
Rosenberg scale & 74.32 \\
Sociological satisfaction questionnaire & 76.17
\end{tabular}

TABLE 2. Internal consistency values of the measuring instruments used

\begin{tabular}{ll}
\hline Scale (item number) & Internal validity \\
$\begin{array}{l}\text { Clubfoot Disease Specific Instrument: } \\
\text { DSI (proxy-reported) }\end{array}$ & 0.872 \\
$\begin{array}{l}\text { Clubfoot Disease Specific Instrument: } \\
\text { DSI (self-reported) }\end{array}$ & 0.923 \\
EQ-5D-3L & 0.831 \\
Rosenberg scale & 0.921 \\
Sociological satisfaction questionnaire & 0.939
\end{tabular}

85.18, median 92.22, SD 20.44). Villages appeared to be an unfavourable factor with the following items: clubfoot inhibiting factor in movement $(U=108.00 ; Z=-1.987 ; p=0.047)$, formation of relationships $(U=118.00 ; Z=-2.00 ; p=0.045)$ ovdje fali jedan parametar $(U=110.00 ; Z=-1.925 ; p=0.05)$ and achieving life goals $(U=105.00 ; Z=-2.097 ; p=0.036)$.

\section{DISCUSSION}

As a result of the transformation of different measuring instruments into a uniform 0-100 system, we can assess the deformity impact from the mean values in our measurements. In other words, the degree of decreased quality of life can be observed in cases of clubfoot (Table 1).

Clubfoot showed greatest impact on a specific quality of life questionnaire, also verifying the efficacy of the measuring instruments. It was followed by the parental DSI, which also strengthened the use of specific questionnaires, and then the psychological aspect, whereas the sociological and general quality of life were least affected in case of clubfoot. The applicability of the questionnaires used to measure the aspects of the quality of life factors separately is indicated by the high internal consistency values (Table 2).

In the international comparison of the DSI (proxy-reported) questionnaire, we get similar values; the satisfaction subscale was 0.851 (Dietz value 0.85), function subscale 0.738 (Dietz value 0.78), and full questionnaire had Chronbach alpha value of 0.872 , which was 0.74 in Dietz test (5).

The use of the questionnaires used to measure the quality of life aspects, quality factors were indicated by high Spearman correlation values (Table 3).

The closest correlation found between our own (self-reported) DSI questionnaire and our own sociological questionnaire was possible because the ad hoc sociological ques-

TABLE 3. Correlation among the measuring instruments

\begin{tabular}{|c|c|c|c|c|c|}
\hline & Self DSI & Proxy DSI & Rosenberg & EQ-5D & Sociological \\
\hline Self DSI & & $\begin{array}{l}r s=0.870 \\
p<0.001 \\
n=19\end{array}$ & $\begin{array}{l}r s=0.684 \\
p<0.001 \\
n=37\end{array}$ & $\begin{array}{l}r s=0.861 \\
p<0.001 \\
n=37\end{array}$ & $\begin{array}{l}r s=0.916 \\
p<0.001 \\
n=37\end{array}$ \\
\hline Proxy DSI & $\begin{array}{l}r s=0.870 \\
p<0.001 \\
n=19\end{array}$ & & $\begin{array}{l}r s=0.539 \\
p=0.017 \\
n=19\end{array}$ & $\begin{array}{l}r s=0.747 \\
p<0.001 \\
n=19\end{array}$ & $\begin{array}{l}r s=0.782 \\
p<0.001 \\
n=19\end{array}$ \\
\hline Rosenberg & $\begin{array}{l}r s=0.684 \\
p<0.001 \\
n=37\end{array}$ & $\begin{array}{l}r s=0.539 \\
p=0.017 \\
n=37\end{array}$ & & $\begin{array}{l}r s=0.602 \\
p<0.001 \\
n=37\end{array}$ & $\begin{array}{l}r s=0.718 \\
p<0.001 \\
n=37\end{array}$ \\
\hline EQ-5D & $\begin{array}{l}r s=0.861 \\
p<0.001 \\
n=37\end{array}$ & $\begin{array}{l}r s=0.747 \\
p<0.001 \\
n=19\end{array}$ & $\begin{array}{l}r s=0.602 \\
p<0.001 \\
n=37\end{array}$ & & $\begin{array}{l}r s=0.884 \\
p<0.001 \\
n=37\end{array}$ \\
\hline Sociological & $\begin{array}{l}r s=0.916 \\
p<0.001 \\
n=37\end{array}$ & $\begin{array}{l}r s=0.782 \\
p<0.001 \\
n=19\end{array}$ & $\begin{array}{l}r s=0.718 \\
p<0.001 \\
n=37\end{array}$ & $\begin{array}{l}r s=0.884 \\
p<0.001 \\
n=37\end{array}$ & \\
\hline
\end{tabular}


tionnaire was designed specifically for disease-specific problems. The weakest correlation was obtained between the (proxy-reported) DSI questionnaire and self-evaluation measuring by Rosenberg scale.

\section{CONCLUSION}

Methodological considerations of the measurement of health-related quality of life and their fulfilment in our study of the quality of life of those living with clubfoot are specified below (13):

Objectivity versus subjectivity: both aspects are important in practice and objectivity should be complemented by subjective reports. These areas can complement each other.

General versus specific: using the EQ-5D-3L (general), it was possible to compare the quality of life of those living with clubfoot to the results of healthy population and other patient groups. On comparison with healthy population, the data greatly varied. The dimensions may be too general and do not relate directly to the disease, so it is absolutely necessary to measure the specific quality of life with the tool of DSI.

Self-reported quality of life or quality of life determined by others: according to Guyatt et al., parents' responses in case of patients aged $>11$ years do not adequately assess the quality of their child's life (19). According to our results, there was a close correlation between parental and responses of children aged 12-18, so under the age of 12 it is better to ask the person concerned to complete the HRQOL questionnaire.

Reliability: internal consistency of all subjective measuring instruments used was appropriate.

Validity: the DSI questionnaire and the dimensions of the EQ-5D questionnaire examined the possible co-movement with convergence validity and we found medium and strong correlation values between the two instruments, as well as among the four questionnaires.

In conclusion, the methods of clinical evaluation do not reflect accurately how children use their feet in daily life and what problems they pose for the child/parent. Self-evaluation coupled with physician's evaluation can help create a better picture of the patient somatic, psychological and social aspects. Thus, subjective factors influencing individual subjective self-assessment and the quality of life of patients with congenital structural clubfoot need to be assessed.

Studies have shown that medical interventions performed are considered to be very successful if they have a positive effect on the quality of life, based on the subjective opinion of the child and the parent. Our study can encourage re- searchers to develop or use new methods/techniques and develop procedures that are functional and can really change the patient quality of life.

\section{Abbreviations:}

AOFAS - Ankle/Foot Scale (Ankle/Hindfoot and Midfoot Scales)

ASK - Activities Scale for Kids

CHQ - Child Health Questionnaire

DSI - Clubfoot Disease Specific Instrument

$\mathrm{FFI}$ - Foot Function Index

FSIIr - Functional Status Questionnaire (Pediatric Functional Status) (MOS) SF-36 - (Medical Outcome Study) Short Form 36 Health Survey SF-12 PCS - Short Form 12 Health Survey Physical Component Summary SF-12 MCS - Short Form 12 Health Survey Mental Component Summary PedsQL - Pediatric Quality of Life Inventory

PODCI - Pediatric Outcomes Data Collection Instrument OxAFQ-C - Oxford Ankle Foot Questionnaire for Children EQ-5D - EuroQol

EQ-VAS - EuroQol Visual analogue scale

AAOS - Association of Orthopaedic Surgeons

HRQOL - Health-Related Quality of Life

\section{REFERENCES}

1. Roye BD, Vitale MG, Gelijns Ac, et al. Patient-based outcomes after clubfoot surgery. J Pediatr Orthop. 2001;21:42-9.

2. Vitale MG, Choe JC, Vitale MA, et al. Patient-based outcomes following clubfoot surgery: a 16-year follow-up study. J Pediatr Orthop. 2005;25: 533-8.

3. Bor N, Coplan JA, Herzenberg JE. Ponseti treatment for idiopathic clubfoot minimum 5-year follow up. Clin Orthop Relat Res. 2009;467:1263-70.

4. Morris C, Doll HA, Wainwright A, et al. The Oxford Ankle Foot questionnaire for children. Bone Joint J. 2008;90-Bsz:1451-6.

5. Dietz FR, Tyler MC, Leary KS, et al. Evaluation of a disease-specific instrument for idiopathic clubfoot outcome. Clin Orthop Relat Res. 2009;467:1256-62.

6. Engell V, Damborg F, Andersen $M$, et al. Health-related quality of life in congenital clubfoot. J Bone Joint Surg, 2009;291-B:Suppl I 56.

7. Wallander $\mathrm{H}$, Larsson $\mathrm{S}, \mathrm{Bjönnes} \mathrm{T}$, et al. Patient-reported outcome at 62 to 67 years of age in 83 patients treated for congenital clubfoot. J Bone Joint Surg Br. 2009;91-B:1316-21

8. Graf A, Hassani S, Krzak J, et al. Long-term outcome evaluation in young adults following clubfoot surgical release. J Pediatr Orthop. 2010;30:379-85.

9. Church Ch, Coplan JA, Poljak D, et al. A comprehensive outcome comparison of surgical and Ponseti clubfoot treatments with reference to pediatric norms. J Child Orthop. 2012;6:51-69.

10. Duffy CM, Salazar JJ, Humphreys L, et al. Surgical versus Ponseti approach for the management of CTEV: a comparative study. J Pediatr Orthop. 2013;33:326-32.

11. Chu A, Chaudhy S, Sala DA, et al. Calcaneocuboid arthrodesis for recurrent clubfeet: what is the outcome at 17-year follow-up? J Child Ortop. 2014;8:43-8

12. Sætersdal C, Fevang JM, Bjørlykke JA, et al. Ponseti method compared to previous treatment of clubfoot in Norway. A multicenter study of 205 children followed for 8-11 years. J Child Orthop. 2016;10:445-52.

13. Lin XJ, Lin IM, Fan SY. Methodological issues in measuring quality of life. Tzu Chi Med J. 2013;25:8-12.

14. Kiss P. Az önértékelés, elégedettség és identitás személyes és társadalmi vetületei. In: Kiss P. (szerk.): Emberi kapcsolatok és társadalmi nézetek kérdőív skáláinak megbízhatósági és érvényességi vizsgálata. Eötvös Kiadó, Budapest, 2009. 
15. Sallay V, Martos T, Földvári M, et al. A Rosenberg Önértékelés Skála (RSES-H): alternatív fordítás, strukturális invariancia és validitás. Mentálhigiéné és Pszichoszomatika. 2014;3:259-75.

16. Rózsa S, V. Komlós A. A Rosenberg Önbecsülés Skála pszichometria jellemzői: a pozitívan és negatívan megfogalmazott tételek működésének sajátosságai, Pszichológia. 2014;34:149-74.

17. Urbán R, Szigeti R, Kökönyei Gy. Global self-esteem and method effects: competing factor structures, longitudinal invariance, and response styles in adolescents. Behav Res Methods. 2014;46:488-98.
18. Szokolszky Á. Kutatómunka a pszichológiában. Osiris Kiadó, Budapest 2004.

19. Guyatt $\mathrm{GH}$, Juniper $\mathrm{E}$, Griffith $\mathrm{LE}$, et al. Children and adult perceptions of childhood asthma. Pediatrics. 1999;2:165-68.

20. Rigó A, Kökönyei Gy. Az életminőséggel kapcsolatos fő szakirodalmi kérdések krónikus szomatikus betegséggel élők körében. Alk Pszichol. 2014;14:5-14.

\title{
Retrospektivno ispitivanje zdravstvene kvalitete života u kongenitalnom ekvinovarusu (s ishodima prijavljenim od strane bolesnika)
}

\author{
Aliz Bohner-Beke, Szilvia Jámbori, Lívia Vass, János Kránicz, Veronika Végh, Henriette Pusztafalvi
}

Kod liječenja pes ekvinovarusa, liječnici su skloniji objektivnim mjerenjima, dokje poznavanje subjektivne kvalitete života pacijenta sekundarno, a ne promatrano istodobno. Cilj je bio istaknuti značaj izvještavanja bolesnika u upitnicima o kvaliteti života. Ova retrospektivna studija obuhvatila je 75 bolesnika s ekvinovarusom (44 dječaka i 28 djevojčica, prosječne dobi 12,45 (raspon 2-30 godina; 3 nedostaju). Liječenje je bilo tipično u 55 bolesnika (posteromedijalno otpuštanje), dok je Ponseti metoda primijenjena u 20 bolesnika. Upotrijebljeni su sljedeći upitnici: EQ-5D-3L i Clubfoot Disease Specific Instrument for Health Science, Rosenberg Scale for Psychological Sapiens i naš vlastiti sociološki upitnik. Prosječni EQ-5D indeks bio je 0,86, a srednji EQ-VAS 79,92, što je niže od podataka za mađarsku populaciju. Prema rezultatima posebnog upitnika o kvaliteti života, bol u stopalima i pronalaženje odgovarajućih cipela uzrokovali su najveće probleme bolesnicima uključenim u ispitivanje. Rezultati upitnika o kvaliteti života pokazali su da je pronalaženje odgovarajućih cipela koje neće dovesti do pogoršanja boli bio najveći problem za sudionike studije. Prosječni skor Rosenbergove ljestvice bio je 22,2 (maksimalno 30) bodova. U pojedinim slučajevima nije bilo značajnih nalaza, međutim, korelacije su pronađene prilikom ispitivanja u skupini sudionika s niskom samoprocjenom. Unutarnja konzistenthost korištenih instrumenata bila je prikladna (Cronbach alfa: 0,831-0,939), a kombinirani upitnici korišteni su za identifikaciju svakog aspekta kako je naznačeno srednjim i visokim Spearmanovim korelacijskim vrijednostima (rs =0,539-0,916).

Ključne riječi: PES EKVINOVARUS; KVALITETA ŽIVOTA; MJERE ISHODA PRIJAVLJENE OD STRANE PACIJENATA 